\title{
Iconology Analysis in Advertising Design, Case Study Go-Jek Billboard Advertising: Series Mager Tanpa Laper in Yogyakarta-Indonesia
}

\author{
Arif Ardy Wibowo ${ }^{\mathrm{a}, 1, *}$, Peter Ardhianto ${ }^{\mathrm{b}, 2}$ \\ ${ }^{a}$ Communication Department, Universitas Ahmad Dahlan Yogyakarta, 55166 Indonesia, \\ ${ }^{\mathrm{b}}$ Ph.D. Program in Dept. of Digital Media Design, Asia University, Taichung, 41354 Taiwan. \\ ${ }^{1}$ arif.wibowo@ comm.uad.ac.id *; ${ }^{2} 108251019 @$ gm.asia.edu.tw \\ * corresponding author
}

ARTICLE INFO

Article history

Received 2019-10-13

Revised 2019-11-07

Accepted 2020-06-06

Keywords

Iconology

Billboard

Advertising

Design

Go-Jek

\section{ABSTRACT}

Billboard is one of the outdoor media that still has a vital role in the world of advertising despite being in the digital age. Billboard advertising is still used by a large number of companies to promote their products or services. One of them is Go-Jek Indonesia's online transportation company. This research will discuss the concept of the Go-Jek billboard advertisement, the Mager Tanpa Laper version in Yogyakarta. This study will use the iconographic and iconological approach offered by Erwin Panofsky. The method is then used to analyze the concept of GoJek advertising. The results of this study found that the advertising version of Go-Jek Mager Tanpa Laper brings an understanding that wants to be transferred to the target market in the form of ease and convenience in ordering food. Without the need to get out of the house and queue up - as evidenced by the tagline Mager Tanpa Laper (Lazy to Move), just Go-Jekin (use the Go-Jek Application).

This is an open-access article under the CC-BY-SA license.

\section{Introduction}

The advance of technology has caused various companies in Indonesia to be more creative, effective, and efficient in conveying messages in various promotions conducted. One of its developments is in the field of advertising. Advertising plays a vital role in selling a product [1]. Multiple methods are used by companies to attract the interests of customers - various types of media used as a way to achieve satisfying results, both print and electronic [2]. However, effective advertising is advertising that is close and can be understood by the target. Each product competes in creating advertisements displayed following their respective targets [3]. The ad made by the company is certainly very varied because the target owned by the company is different. In effect, approaches to creating visual designs have also become diverse. Therefore, this study intends to examine the issue of visual design products in depth. Bandura argues that an advertisement is a deliberate depiction made to influence and tell what is needed and desired by the public through a media that has goals on the behavior of a product [4]. Past, the use of advertising was a way of attracting the market, as well as differentiating a product from other similar items or competitors. An ad must be attractive, but it must also be able to penetrate various aspects of the human mind so that it takes several things to form a good advertisement. Advertising itself is a medium for communicating and conveying messages from producers to their target market [5]. Because advertising requires the media to express its purpose, the company must consider the choice of place and type of media used. 
Gojek's journey began in 2010 as a motorcycle ride-hailing call center in Indonesia. The homegrown app was then launched in 2015 with only three services: GoRide, GoSend, and GoMart. Since then, the app has evolved into a Super App, a multi-services platform with more than 20 services today. Gojek is now a leading technology group of platforms serving millions of users in Southeast Asia [6]. Go-Jek Indonesia is one of the companies that are on the rise in Indonesia. It is a mobile application provider that offers a full range of services ranging from transportation, logistics, payment services, and other services. Go-Jek develops various innovations in its services as a solution and convenience in dealing with the problems of today's society. Services offered in the Go-Jek application include Go-Ride, Go-Car, Go-Food, Go-Credit, Go-Send Go-Point, Go-Bills, Go-Box, Go-Shop, GoMart, Go-Tix, Go-Med, and Go-Pay. Among the many services provided by Go-Jek, Go food is one of the most widely used by users. From the data released by Go-Jek, in 2018, more than 500 million have been successfully delivered by Go-Jek through the Go Foodservice [7]. Figure 1 is a variety of Go-Jek services.

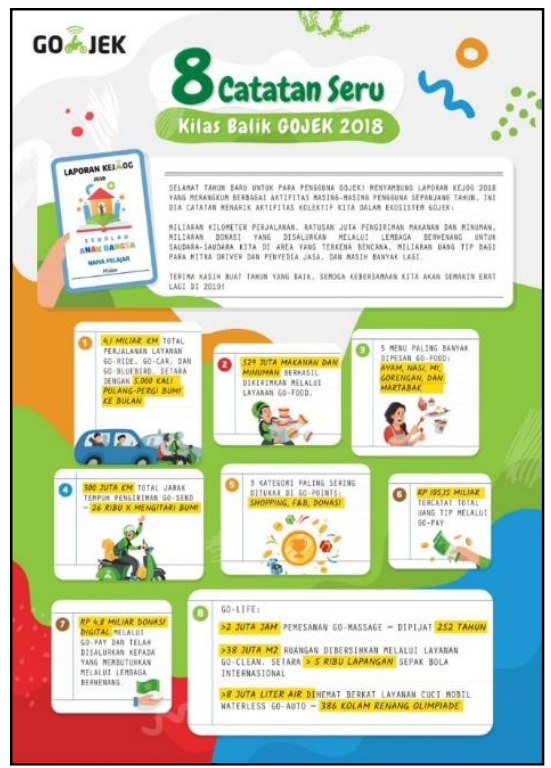

Fig. 1. The variety of Go-Jek services [8]

Visual data in Figure 1 is one of the new advertising data. The choice of the form of advertisements that will be displayed, pay attention to creative strategies, and this is by the selected product target. The statement from Belch that advertising is deliberately designed rationally, taking into account the logic of the target audience of consumers in making choices, but also trying to touch emotionally as well [9]. With the emotional touch, the opportunity for consumers to become loyal to a product will be even higher. Advertising can be said to be useful if the delivery has a logical reason to buy products with emotional values [10]. The iconological analysis is used in this study because it will make it very easy to find out a concept behind the work of advertising [11]. Every Go-Jek advertisement is made with various backgrounds, so it requires visual analysis. Visual analysis of an ad is very appropriate to use the study of iconology because it will reveal the meaning and concepts behind it. Go-Jek advertisements displayed so far are unique depending on the services offered so that visual advertising will always be varied and creative. By analyzing the iconology, we will get something different because of the ideological elements associated with the socio-cultural conditions where an advertisement has placed [12].

\section{Methods}

The study carried out to adjust to the object to be studied because each object studied has its character. The Go-Jek billboard study, a descriptive approach will be used. The use of this approach is felt to be more comfortable for writers and readers because, in this method, the object of study will explain and explain clearly. The use of a qualitative approach is the approach used in this Go-Jek billboard study. Morrison states that qualitative research is a series of interpretive practices, which in this study does not favor one methodology. Which conducts interpretive practices, in which the researcher gets a better understanding of the subject of the study at hand [13]. Data collection is done 
by direct observation and documentation using the camera. In a study, especially the study of art to be carried out, observations are essential to do.

Kao revealed that in design observation, a systematic description of how the design was made, the behavior of the designer, and the results of the design produced, the data of these three things could be known [14]. In this study, the observation method chose because the researcher was not directly involved physically or emotionally with the work to be discussed. After documenting and observing, the analysis method in this study uses analysis of iconography and iconology [11], to interpret the visual of designs and tagline messages used in the Go-Jek billboard ad. The population of this study is Go-Jek Advertisements in Yogyakarta. In Yogyakarta Area, there are many Go-Jek billboards with 1-2 months duration before being replaced with other billboards. The data used is the Go-Jek Go Food Mager Tanpa Laper billboard series in several areas in Yogyakarta, such as Jalan Bantul and Mataram Sewers. The ad series Mager Tanpa Laper is an ad that carries the contemporary theme of the younger generation, with the slang word mager, which stands for malas gerak or lazy to move-shown in Figure 2.

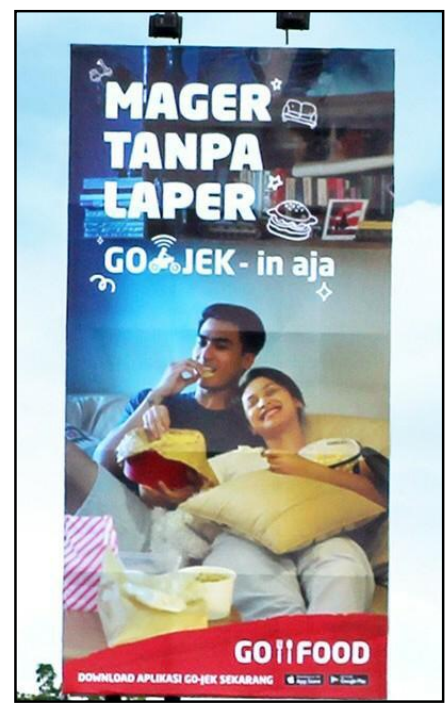

Fig. 2. Ads. Design Billboard Go-Jek Mager Tanpa Laper Source: Wibowo, 2019

Data analysis was performed by describing all data that had been obtained. The stages of the study followed the procedure, starting from observation, data processing, and data analysis. The analysis process ends with presenting conclusions. See Figure 3.

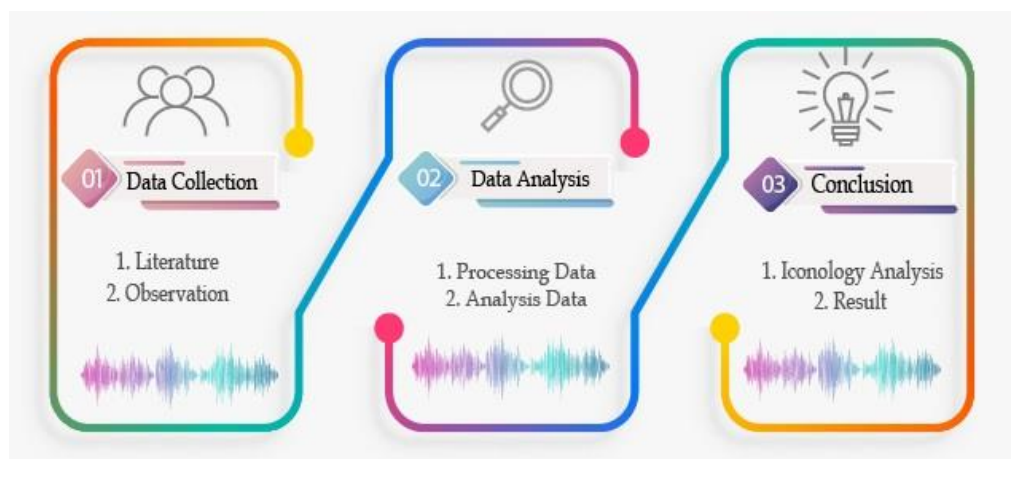

Fig. 3.Research Flow

\section{Result and Discussion}

\subsection{Advertising and Types of Advertising}

An advertisement is a method used by a company to introduce the right product or service so that it can easily reach out and attract the interest of the target audience [15]. The three aspects that makeup advertising are communication (communicative and persuasive advertising), marketing (Ads that 
sell), and art (Visually appealing Ads) [16]. Generally, there are only two types of advertisements. Commercial advertisements aimed at selling/promoting/introducing a product or service. While noncommercial advertising aims to sensitize the public or invite the community without any product/service selling factor, furthermore, if the user sees how it spread, advertisements can be divided into several types [17]. Golan states that there are six categories of advertisements based on their distribution media [18], such as:

- Print Media Ads: Ads that published in print media, including newspapers, and tabloids

- Radio Ads: Ads that played and spoken by radio broadcasters

- Television Ads: Ads appear on television

- Outdoor Media Ads: Ads placed in public spaces such as billboards, banners, and Videotron's.

- Cinema Ads: Ads shown at the time of movie screening in theaters.

- Internet Advertising / Digital Advertising: Ads that use social media, such as Facebook, Twitter, Youtube, and Mobile Advertising for Smartphones.

Based on several types of advertisements, the Advertising Billboard Room was chosen as study material, although Go-Jek also made advertisements with other media. It is because billboards still have the power as one of the spearheads of promotion despite being accompanied by various advertisements on social media [19]. Billboard is an effective medium to attract attention from readers by its large size and looks from a distance into consideration ad producers in placing ads [20]. Placement of billboards in strategic places that are passed by many people in Indonesia, especially Yogyakarta, still makes this media one of the leading choices in offering products from Go-Jek.

\subsection{Iconological Analysis}

The analysis that will use in this study is using the Iconology theory [21], which refers to Gillian Dyer's theory [22]. As for analyzing the iconography of visual advertising, this study uses the concept of analysis from Erwin Panofsky. According to Panofsky, studying art can take three stages. The first stage is called Pre Iconography, which describes the work vision. The second stage is called Iconography, which gives rise to the second meaning of the visual advertisement that has been described. The third stage is Iconology, which concludes the philosophical views or ideas behind a work [23]. The Comparative Table of Iconology Approach can be seen in Table 1.

Table 1. Comparative Table of Iconology Approach

\begin{tabular}{cc}
\hline Erwin Panofsky (1955) $($ Art $)$ & Gillian Dyer (1982) (Advertising) \\
\hline Pra-iconography & Denotation \\
\hline Iconography & Connotation \\
\hline Iconology & Iconology (Ideology) \\
\hline
\end{tabular}

This model was adopted by Dyer, who argued that iconological analysis of advertising could be carried out in three levels, which is denotative level (explicit meaning), connotative (implied meaning), and ideological meaning (view of life/philosophy behind the advertisement). With this three-level analysis, we will get the ideology contained in an advertisement through the visuals displayed [22]. The ad analysis process begins by describing all visual elements. Next, the items that have been analyzing in the first stage are interpreted as connotative meanings (in terms of associations/emotions/symbols). The connotative meaning is obtained by connecting all visual elements, including objects, motion, viewpoints, colors with the theme of the ad. Finally, the finding of associative meaning and symbolic meaning in the second stage is related to Go-Jek products, which are the object of advertising and related to the social and cultural context of the community at that time. By this step, the ideological meaning of advertising can be obtained. The results of the Billboard Go-Jek Mager Tanpa Laper Analysis of Iconology using iconology analysis from Gillian Dyer can see in the following discussion:

\subsubsection{Denotative Description}

The formal description of the Go-Food billboard is the background of this ad using images of young couples. The young couple was seen sitting relaxed on the couch with their hands holding food. They look happy because they show facial expressions that smile while enjoying their food. This 
billboard's size is approximately $7 \times 3$ meters on a vertical orientation. While at the top left of the billboard, there is the text written: "Mager Tanpa Laper, Go-Jek-In Aja." This text is white and has added with ornaments such as burgers and sofas. Mager is a contemporary language that is often used by young people. Mager is an abbreviation of Malas Gerak, which is generally used to describe a situation that is reluctant to leave the house. In the bottom right corner of the billboard, there is a GoFood logo with a red background with white writing. Below Go food, there is a text "Download Aplikasi Go-Jek Sekarang," followed with the logo of App Store and Google Play.

\subsubsection{Connotative Description}

The connotative description explains the second meaning that comes from the visual. Go-Food billboard visualized a picture of a young couple in a room with a sofa, table, and books on top of them. In the room, they were seen relaxing, sitting on a sofa with their hands holding food. That is, this indicates that after receiving Go-Food services, they can feel the fun, togetherness, and comfort while enjoying food without having to go to a restaurant. The view of male subjects shows a sense of pleasure that is indicated by the direction of looking straight ahead with a smile expanding while biting food. He also showed his pleasure by smiling broadly. Likewise, the woman, her eyes closed, indicating that she was experiencing the pleasure of food. There are colors used in the design of this ad, such as blue, yellow, red, and white. Blue is referred to as a corporate color because the blue color can give a professional impression and trust. Blue is believed to stimulate the ability to communicate, and also as a symbol of strength. In this ad, the blue color is used in the background color section, and also in clothing worn by male models. Furthermore, the color yellow, this color used on parts such as pillows held by female models, women's clothing, sofas, and food. Yellow used because it can attract attention and has the meaning of warmth, cheerfulness, and happiness. That is harmony pose smiling woman who is leaning on the sofa wearing a yellow shirt and food in her hand. Then the red color is used to give the impression of prominence to attract more attention. The red color usually interpreted as a symbol of strength, enthusiasm, and courage. Furthermore, red is also able to stimulate the appetite. Color implementation is one subconscious cue that marketers utilize in today's advertisements [24].

There is a red color in this ad placed on the background of the Go-Food logo and food container. Indirectly the use of the red color provides information to the public to remember the identity that GoFood is a food delivery service that can help customers when hungry but cannot go outside. Then there is white used as the font color in words "Mager Tanpa Laper, Go-Jekin." The white color in this paper gives the impression of clean, freedom, open, and simple. It is the same as that offered in Go-Food services. Clean means food that will be delivered by the driver will be brought carefully, also maintained cleanliness. This freedom means that customers can freely order whatever food they want. Openness intended that the driver will always be ready to help customers to get the food as they wish. Simple shows that to use the Go-Food service is effortless by merely pressing the Go-Food icon available in the Go-Jek application; then, the customer chooses the desired food. The message contained in this billboard ad written with the words "Mager Tanpa Laper, Go-Jekin Aja," the use of this sentence indirectly invites people who are lazy and cannot go out to buy food, they can rely on Go-Food services from Go-Jek. If seen from the approach of communication with the visual ad, the main target of this ad is young people who live in big cities like Yogyakarta. The sentence gives a new impression because it uses the word Mager, which is one of the words that are often used by young people in getting along. The Ad's ornaments are pictures of motorcycles, burger, and sofas, which indirectly become icons. The motor icon marks the Go-Jek driver, then the burger icon marks the food that ordered on the Go-Food service, and the sofa icon indicates that customers can relax while waiting and enjoy the food that arrives. On the bottom of the ad. can see a text "Download Aplikasi Go-Jek Sekarang," which means Download Gojek App Now, followed by Logo App Store and Google Play. App Store and Google Play are digital stores where Gojek App can be download.

\subsubsection{Iconology Interpretation}

From the analysis that has found previously, describe that in Go-Jek's advertisement, it has the meaning of an ideology that wants to be conveyed for customers when using the Go-Jek food service from Go-Jek. Go-Food service intended for customers who are unable to go out looking for food by using the Go-Food service so that the desired food is quickly delivered by the Go-Jek driver so that it helps customers to save time. On the other hand, Yogyakarta's traffic conditions, known for its small road and traffic jams, make many food customers reluctant to go out to buy the desired food. Using this app, customers can easily enjoy Go-Food services by merely pressing the Go-Food icon in the 
Go-Jek application. The following meaning is simple, marking that in using Go-Food services, there is no need to bother pressing many confusing buttons. Customers can choose their desired food; After that, he can relax, sit relaxed while waiting for food to come, until the food comes and is ready to be enjoyed.

Simple in using Go-Food services means that food can be sent to the house without leaving home. Indirectly, Go-Food provides information to the public with the services it offers, which are practical, easy to use, and can be trusted. Go-Food products from Go-Jek seem to convey that, a food message solution without difficulty and can be done when lazy is to use Go-Food digital application products. Practicality is a solution that is equally good for the buyer and also the company Go-Jek and food sellers registered on digital applications. The use of the word Mager is also a statement that the target market of this ad is aiming for young people. The word Mager is an abbreviation of "Malas Gerak" or lazy to move, which is often used by young people in Yogyakarta. Today young people are the most internet users, so they are more easily influenced when advertisements use words that are often used by them.

\section{Conclusion}

The study concludes that the Billboard Go-Jek Go-Food advertisement Mager Tanpa Laper is visual communication that contains information on the ease of ordering food. Customers easily enjoy the food menu without leaving home and waiting in line. As evidenced by the tagline "Mager Tanpa Laper, Go-Jekin Aja" wrote. Go-Food's service appears because of the problems of the traffic jam of Yogyakarta so that there is a sense of reluctance from the public to go out to find food. Besides, the busy work that takes up much time, making meetings with family at home is a pleasure coupled with the ease of ordering food. Young people are the most internet users, so they are the main target of this ad - a pair of young people become models to attract their interest using the Go-Food application. Young people are very busy with their schedules, so this application will no doubt facilitate their needs in eating. The use of the word Mager which is slang for Indonesian children today is an affirmation that the main target of this ad is the young generation. Besides, an advantage offered in Go-Food services and also maintained the cleanliness of food. Customers can easily enjoy Go-Food services by merely pressing the Go-Food icon in the Go-Jek application. Using the Go-Food application is very easy; customers do not have to bother pressing many phone buttons. Customers can choose food; after that, they can relax, sit while waiting for food when the food ordered has arrived, customers are ready to enjoy. Using Go-Food services can create a sense of pleasure and warmth. The Conclusion, GoFood provides information to the public with the services it offers, which are practical, easy to use, and straightforward.

\section{References}

[1] I. Buil, L. de Chernatony, and E. Martínez, "Examining the role of advertising and sales promotions in brand equity creation,” J. Bus. Res., vol. 66, no. 1, pp. 115-122, Jan. 2013, doi: 10.1016/j.jbusres.2011.07.030.

[2] M. Zhang, L. Guo, M. Hu, and W. Liu, "Influence of customer engagement with company social networks on stickiness: Mediating effect of customer value creation," Int. J. Inf. Manage., vol. 37, no. 3, pp. 229240, Jun. 2017, doi: 10.1016/j.ijinfomgt.2016.04.010.

[3] A. de Cornière, "Search Advertising," Am. Econ. J. Microeconomics, vol. 8, no. 3, pp. 156-188, Aug. 2016, doi: $10.1257 / \mathrm{mic} .20130138$.

[4] A. Bandura, "Social Cognitive Theory of Mass Communication," Media Psychol., vol. 3, no. 3, pp. 265299, Aug. 2001, doi: 10.1207/S1532785XMEP0303_03.

[5] P. Ardhianto and W. Manuel Son, "Visual Semiotics Analysis on Television Ads UHT Ultra Milk 'Love Life, Love Milk," Int. J. Vis. Perform. Arts, vol. 1, no. 1, pp. 27-41, Jun. 2019, doi: 10.31763/viperarts.v1i1.13.

[6] J. Paundra, J. van Dalen, L. Rook, and W. Ketter, "Ridesharing platform entry effects on ownership-based consumption in Indonesia," J. Clean. Prod., vol. 265, p. 121535, Aug. 2020, doi: 10.1016/j.jclepro.2020.121535. 
[7] T., I. Maftukhah, F. Dyah Rahmawati, and A. Fadlilah, "Considering the Influence of Digital Promotion Performed By Go-Jek Indonesia and C2C Marketplaces on Buyers' Purchasing Decision,” KnE Soc. Sci., vol. 3, no. 10, p. 541, Oct. 2018, doi: 10.18502/kss.v3i10.3155.

[8] Rajendra, “Apresiasi Pengguna, Gojek Hadirkan Kilas Balik Laporan KEJOG 2018,” Nusa Kini, 2019. [Online]. Available: https://www.nusakini.com/news/apresiasi-pengguna-gojek-hadirkan-kilas-baliklaporan-kejog-2018.

[9] G. E. Belch and M. A. Belch, Advertising and promotion: An integrated marketing communications perspective. The McGraw- Hill, 2003. available at: Google Scholar.

[10] M. B. Holbrook and J. O’Shaughnessy, “The role of emotion in advertising," Psychol. Mark., vol. 1, no. 2, pp. 45-64, 1984, doi: 10.1002/mar.4220010206.

[11] M. G. Müller, "Iconography and Iconology as a Visual Method and Approach," in The SAGE Handbook of Visual Research Methods, 1 Oliver's Yard, 55 City Road, London EC1Y 1SP United Kingdom: SAGE Publications Ltd, 2011, pp. 283-297. doi: 10.4135/9781446268278.n15.

[12] Wjt. Mitchell, "Iconology and Ideology: Panofsky, Althusser, and the Scene of Recognition," in Image and Ideology in Modern/PostModern Discourse, SUNY Press, 1991, pp. 321-330. available at: Google Scholar.

[13] M. A. Morrison, E. Haley, K. B. Sheehan, and R. E. Taylor, Using qualitative research in advertising: Strategies, techniques, and applications. Sage Publications, 2011. available at: Google Books.

[14] T.-F. Kao and Y.-Z. Du, "A study on the influence of green advertising design and environmental emotion on advertising effect," J. Clean. Prod., vol. 242, p. 118294, Jan. 2020, doi: 10.1016/j.jclepro.2019.118294.

[15] C. Veloutsou and C. O'Donnell, "Exploring the effectiveness of taxis as an advertising medium," Int. J. Advert., vol. 24, no. 2, pp. 217-239, Jan. 2005, doi: 10.1080/02650487.2005.11072915.

[16]A. Anagnostopoulos, A. Z. Broder, E. Gabrilovich, V. Josifovski, and L. Riedel, "Just-in-time contextual advertising," in Proceedings of the sixteenth ACM conference on Conference on information and knowledge management - CIKM '07, 2007, p. 331, doi: 10.1145/1321440.1321488.

[17] A. Kerkhof and J. Münster, "Quantity restrictions on advertising, commercial media bias, and welfare,” J. Public Econ., vol. 131, pp. 124-141, Nov. 2015, doi: 10.1016/j.jpubeco.2015.09.004.

[18]G. J. Golan and L. Zaidner, “Creative Strategies in Viral Advertising: An Application of Taylor's SixSegment Message Strategy Wheel,” J. Comput. Commun., vol. 13, no. 4, pp. 959-972, Jul. 2008, doi: 10.1111/j.1083-6101.2008.00426.x.

[19]I. M. Chaney, K.-H. Lin, and J. Chaney, “The Effect of Billboards within the Gaming Environment," J. Interact. Advert., vol. 5, no. 1, pp. 37-45, Sep. 2004, doi: 10.1080/15252019.2004.10722092.

[20] G. R. Franke and C. R. Taylor, "Public Perceptions of Billboards: A Meta-Analysis," J. Advert., vol. 46, no. 3, pp. 395-410, Jul. 2017, doi: 10.1080/00913367.2017.1334248.

[21] M. Barnard, "Book Review: Visual Consumption,” J. Consum. Cult., vol. 3, no. 1, pp. 126-128, Mar. 2003, doi: 10.1177/146954050300300108.

[22] G. Dyer, “Advertising — System and Texts," Media Inf. Aust., vol. 31, no. 1, pp. 5-12, Feb. 1984, doi: $10.1177 / 1329878 \times 8403100103$.

[23] C. Hasenmueller, "Panofsky, Iconography, and Semiotics," J. Aesthet. Art Crit., vol. 36, no. 3, p. 289, 1978, doi: 10.2307/430439.

[24] R. Sparkman and L. M. Austin, "The Effect on Sales of Color in Newspaper Advertisements," J. Advert., vol. 9, no. 4, pp. 39-42, Dec. 1980, doi: 10.1080/00913367.1980.10673336. 